Abstracta Iranica Abstracta Iranica

Revue bibliographique pour le domaine irano-aryen

Volume 27 | 2006

Comptes rendus des publications de 2004

Studies in Muslim Apocalyptic. Studies in Late Antiquity and Early Islam, 21, Princeton, The Darwin Press, 2002.

Antoine Borrut

(2) OpenEdition

Journals

Édition électronique

URL : http://journals.openedition.org/abstractairanica/6179

ISSN : 1961-960X

Éditeur :

CNRS (UMR 7528 Mondes iraniens et indiens), Éditions de l'IFRI

Édition imprimée

Date de publication : 15 mai 2006

ISSN : 0240-8910

Référence électronique

Antoine Borrut, «Studies in Muslim Apocalyptic. Studies in Late Antiquity and Early Islam, 21, Princeton, The Darwin Press, 2002. », Abstracta Iranica [En ligne], Volume 27 | 2006, document 258, mis en ligne le 02 janvier 2007, consulté le 25 septembre 2020. URL : http://journals.openedition.org/ abstractairanica/6179

Ce document a été généré automatiquement le 25 septembre 2020.

Tous droits réservés 


\title{
Studies in Muslim Apocalyptic. Studies in Late Antiquity and Early Islam, 21, Princeton, The Darwin Press, 2002.
}

\author{
Antoine Borrut
}

1 D. Cook livre ici un ouvrage important dans la mesure où il présente, pour la première fois, une étude globale des apocalypses islamiques, tant sunnites que chiites, alors que ce sont ces dernières qui avaient surtout retenu l'attention des chercheurs. L'auteur propose une typologie des cycles apocalyptiques et livre une étude détaillée des différents corpus, dans une perspective comparatiste avec les traditions chrétiennes et juives. Il met ainsi en évidence des processus de transmission réciproques du savoir religieux. Si la Syrie s'affirme comme le lieu privilégié du développement de nombre de ces traditions, l'A. met également en lumière leur circulation dans l'espace iranien et la reprise de cycles hérités des Sassanides, à l'instar de celui de Bahrām Chōbīn.

D. Cook invite à appréhender les apocalypses comme faisant partie intégrante des fondations idéologiques de l'islam premier et comme une branche de la tradition musulmane, tout en stigmatisant les liens étroits qui unissent jihād et apocalyptique musulmane. Il souligne par ailleurs la diminution des traditions apocalyptiques dans le monde sunnite après 250/864 et après environ 350-400/960-1000 dans le monde chiite.

Du point de vue des sources, on notera l'étude systématique conduite sur le Kitāb alfitan de Nu'aym b. Ḥammād al-Marwazī (m. 229/844), natif de Merv mais qui travailla en Syrie, ouvrage capital, encore insuffisamment étudié. Il faut insister enfin sur la valeur des annexes (nombreuses traductions, références coraniques dans la littérature apocalyptique...) et sur la qualité de l'index, marque de fabrique de la collection. 
INDEX

Thèmes : 7. Islam

\section{AUTEURS}

ANTOINE BORRUT

IFPO - Damas 